\title{
Synthesis, Characterization and Structural Study of New Ethyl Thiourea Compounds and the Preliminary Naked-eye Sensors for Mercury and Argentum Metal lons
}

\author{
SITI AISHAH HASBULLAH*, SYAHIDATUL MUNIRAH RAFFIK, NURNADZIRAH \\ MAT NOH, EMMA IZZATI ZAKARIAH, FATIMATUL AKMA AWANG NGAH, \\ HAMZA MILAD ABOSADIYA and BOHARI YAMIN
}

School of Chemical Sciences and Food Technology, Faculty of Science and

Technology, Universitiy Kebangsaan Malaysia, 43600 Bangi, Selangor, Malaysia.

${ }^{*}$ Corresponding author: aishah80@ukm.edu.my

http://dx.doi.org/10.13005/ojc/330227

(Received: October 09, 2017; Accepted: January 01, 2017)

\begin{abstract}
Novel ethyl thiourea compounds $1 \mathrm{a}-1 \mathrm{f}$ have been synthesized in good to high yields. The structure of all compounds were identified using FT-IR, ${ }^{1} \mathrm{H}$ NMR, ${ }^{13} \mathrm{C}$ NMR spectroscopies, and ESI-Mass spectrometry. The compound 1-ethyl-3-(3-methoxyphenyl) thiourea 1e was obtained in crystalline form by recrystallization from DMSO. Single crystal X-ray analysis revealed that 1e molecule crystallized in a monoclinic crystal system with space group of $\mathrm{P} 21 / \mathrm{n}$ and the unit cell dimensions are $\mathrm{a}=11.0797(7)$ $\AA, b=8.6081(6) \AA, c=11.9698(7) \AA, \alpha=90^{\circ}, \beta=104.543(2)^{\circ}, \gamma=90^{\circ}, Z=4$ and $V=1105.04(12)$ $\AA^{3}$ The preliminary optical sensor properties for metal ions of $\mathbf{1 a}, \mathbf{1 b}$ and $\mathbf{1 d}$ were investigated using naked-eye. The results determined that all compounds have the ability as naked eye sensors for mercury $(\mathrm{Hg})$ and argentum $(\mathrm{Ag})$ metal ions.
\end{abstract}

Keywords: Synthesis; Structural study; Ethyl thiourea; Naked-eye Sensors

\section{INTRODUCTION}

Thiourea is similar to urea compound except the oxygen atom in urea is replaced by the presence of sulphur atom in thiourea compound. ${ }^{1}$ The chemical properties of both compounds are different because of the oxygen and sulphur atoms in urea and thiourea. These atoms have different in electronegativity where oxygen has greater electronegativity compare to sulphur. Many applications can be done on behaviours. ${ }^{2}$ Thiourea is a chemically interesting compound where it has more than two functional groups in a compound: amino, imino and thiol. ${ }^{3}$ Thiourea derivatives are mostly crystalline compounds and thermally stable. They can be produced in good yields from available starting material by simple syntheses. ${ }^{3}$ Thiourea is also one of the most famous studied compounds on 
metallic electrodes. ${ }^{4}$ It can absorb to metal surface and the absorption blocks the active sites. ${ }^{4}$ It is also one of the important industrial chemical products. ${ }^{5}$ Now a days, the situation of environmental pollution by heavy metals is one of the critical issues due to the development of modern industries and agriculture.

Many of heavy metals can be dangerous towards human or animal health. Mercury $\left(\mathrm{Hg}^{2+}\right)$ is one of the most toxic and hazardous between all the heavy metals. ${ }^{6}$ Mercury can cause cells damage and some diseases related to brain, ${ }^{7}$ kidney, and central nervous system. These are because the mercury is unable to decay naturally and accumulates in animal and human bodies. ${ }^{8}$ Silver ions $\left(\mathrm{Ag}^{+}\right)$also have long been known to have strong inhibitory and antimicrobial activities. ${ }^{9}$ Silver nano particles are showing very toxic effects on human health and the environment due to the antibacterial activity. Then, chronic exposure to silver also can causes negative effects such as permanent bluish-grey discoloration of the skin (argyria) and eyes (argyrosis). Besides that, it also may produce other toxic effects like liver and kidney damage, irritation of the eyes, skin, respiratory and intestinal tract and changes to blood cell. ${ }^{10}$ For the above reasons, there is a high demand for tracking these metal ions. ${ }^{11}$ The aim of the present study was to synthesis thiourea compounds having alkyl and aryl group substitutes.

Chemical sensor is generally consisting of two units; receptor unit and signalling unit, but in some cases spacer is also used to provide the shape and geometry in two armed molecule. ${ }^{12}$ Detecting metal cations is one of the great interests to many scientists. ${ }^{13}$ Thioureas are well known having good affinity towards metals via thiono group $(\mathrm{C}=\mathrm{S})$ make them applicable as ion sensors. ${ }^{14}$ The nitrogen, oxygen and sulphur atom are donor atoms of thiourea that can donate electrons to form bonding and provide a multitude of bonding possibilities. ${ }^{15,16}$ The structural characterization of the thiourea derivatives were performed using FTIR, ${ }^{1} \mathrm{H}$ NMR, ${ }^{13} \mathrm{C}$ NMR spectroscopy devices and ESI-MS spectrometry. In order to investigate the sensor properties, the interaction of all compounds with metals in solvent media was investigated using naked-eye sensor.

\section{MATERIALS AND METHODS}

All reactions were performed under conventional reflux method. Chemicals and solvents were purchased from Sigma Aldrich and Across and used directly without any further purification. Melting points were recorded on the open tube capillary method using Electrothermal 9100 instrument (Electrothermal, England) and are uncorrected. All compounds were analyzed using FTIR Perkin Elmer Model Spectrum GX in the range $400-4000 \mathrm{~cm}^{-1}$ using $\mathrm{KBr}$ method, ${ }^{1} \mathrm{H}$ and ${ }^{1} \mathrm{C}$ NMR spectrometer model Bruker Advance $400 \mathrm{MHz}$ and Liquid Chromatography Mass Spectroscopy (ToF) model Dionex/BrukerMicroToF Q. Single-crystal X-ray experiments were performed on a Bruker D-QUEST diffractometer (Bruker, AXS Inc., Madison, WI, USA) using graphite-monochromated Mo-Ka radiation $(\gamma=0.71073 \AA)$. The $\omega$-scan measured the intensity data at room temperature. The full-matrix leastsquares fit of 25 reflections determines the accurate cell parameters and orientation matrix. Intensity data were collected for Lorentz and polarization effects. Empirical absorption correction was carried out using multi-scan. The structure was solved by direct methods and least-squares refinement of the structure was performed by the SHELXL-2007 program. ${ }^{17}$ All the non-hydrogen atoms were refined anisotropically. The hydrogen atoms were placed in the calculated positions except those of the terminal nitrogen atoms of thiourea moieties located from Fourier maps and refined isotropically.

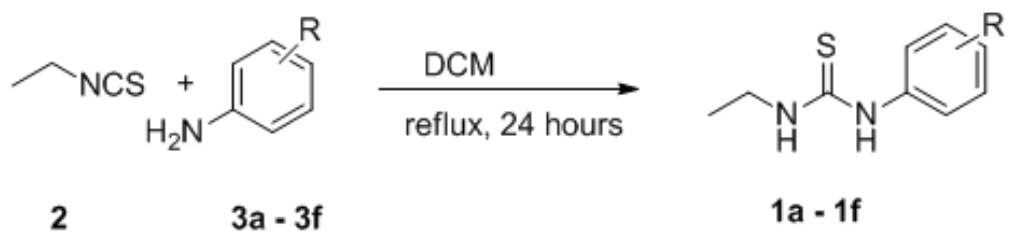

1a, 3a $=\mathrm{R}, 2-\mathrm{CH}_{3}(83 \%)$
1b, 3b $=\mathrm{R}, 3-\mathrm{CH}_{3}(73 \%)$
1c, 3c $=\mathrm{R}, 4-\mathrm{CH}_{3}(85 \%)$
1d, 3d= R, $2-\mathrm{OCH}_{3}(71 \%)$
1e, 3e $=\mathrm{R}, 3-\mathrm{OCH}_{3}(64 \%)$
1f, 3f $=\mathrm{R}, 4-\mathrm{OCH}_{3}(93 \%)$

Scheme 1 Synthesis of ethylthioureas $1 a-1 f$ 
General procedure for synthesis of compounds 1a-1f

A solution of ethylisothiocyanate $(0.1394$ $\mathrm{g}, 0.0016 \mathrm{~mol})$ in dichloromethane $(20 \mathrm{~mL})$ was added dropwise to a suspension of toluidine1a,1 $\mathbf{b}$ or $1 \mathrm{c}(0.1714 \mathrm{~g}, 0.0016 \mathrm{~mol})$ and anisidine $1 \mathrm{~d}, 1 \mathrm{e}$ or $1 \mathrm{f}(0.1968 \mathrm{~g}, 0.0016 \mathrm{~mol})$ in dichloromethane. The reaction mixture was refluxed for 24 hours and was monitored using thin layer chromatography (TLC) until the reaction was completed. The white precipitate was formed and filtered out. The solid product was purified by recrystallization method using ethanol: dichloromethane mixture.

1a Mp: $81.9-83.6^{\circ} \mathrm{C} . \mathrm{IR}(\mathrm{KBr}), \mathrm{NH}: 3193.00$ $\mathrm{cm}^{-1}, \mathrm{C}-\mathrm{N}: 1371.00 \mathrm{~cm}^{-1}, \mathrm{C}=\mathrm{S}: 1245.00 \mathrm{~cm}^{-1} .{ }^{1} \mathrm{H}$ NMR (400 MHz, $\left.\mathrm{CDCl}_{3}-\mathrm{d}_{6}\right) \delta$ (ppm) $1.14(3 \mathrm{H}, \mathrm{t} J=7.2 \mathrm{~Hz}$, $\left.\mathrm{CH}_{3}\right), 2.29\left(3 \mathrm{H}, \mathrm{s}, \mathrm{CH}_{3}\right), 3.63\left(2 \mathrm{H}, \mathrm{s}, \mathrm{CH}_{2}\right), 5.65(1 \mathrm{H}$, s, NH), $7.25(1 \mathrm{H}, \mathrm{d} \mathrm{J}=10.8 \mathrm{~Hz}, \operatorname{ArCH}), 7.26(1 \mathrm{H}, \mathrm{t}$ $\mathrm{J}=7.8 \mathrm{~Hz}, \operatorname{ArCH}), 7.28(1 \mathrm{H}, \mathrm{t} \mathrm{J}=7.8 \mathrm{~Hz}, \operatorname{ArCH}), 7.30$ $(1 \mathrm{H}, \mathrm{d} \mathrm{J}=10.8 \mathrm{~Hz}, \mathrm{ArCH}), 7.84(1 \mathrm{H}, \mathrm{s}, \mathrm{NH}) .{ }^{13} \mathrm{C}$ NMR $\left(100 \mathrm{MHz}, \mathrm{CDCl}_{3}-\mathrm{d}_{6}\right) \delta(\mathrm{ppm}) 14.5\left(\mathrm{CH}_{3}\right), 17.8\left(\mathrm{CH}_{3}\right)$, $40.2\left(\mathrm{CH}_{2}\right), 127.5-131.8(4 \times \mathrm{ArCH}), 135.9(\mathrm{ArC})$, $134.4(\operatorname{ArC}), 180.6(C=\mathrm{S}) . \mathrm{m} / \mathrm{z}(\mathrm{ESI})\left(\mathrm{H}^{+}, \mathrm{C}_{10} \mathrm{H}_{14} \mathrm{~N}_{2} \mathrm{~S}\right.$ requires 195.09)

1b Mp: $84.9-85.6^{\circ} \mathrm{C} . \mathrm{IR}(\mathrm{KBr}), \mathrm{NH}: 3011.00$ $\mathrm{cm}^{-1}, \mathrm{C}-\mathrm{N}: 1355.00 \mathrm{~cm}^{-1}, \mathrm{C}=\mathrm{S}: 1148.00 \mathrm{~cm}^{-1} .{ }^{1} \mathrm{H} \mathrm{NMR}$ $\left(400 \mathrm{MHz}, \mathrm{CDCl}_{3}-\mathrm{d}_{6}\right) \delta(\mathrm{ppm}) 1.18(3 \mathrm{H}, \mathrm{t} \mathrm{J}=7.2 \mathrm{~Hz}$, $\left.\mathrm{CH}_{3}\right), 2.36\left(3 \mathrm{H}, \mathrm{s}, \mathrm{CH}_{3}\right), 3.66\left(2 \mathrm{H}, \mathrm{s}, \mathrm{CH}_{2}\right), 6.01(1 \mathrm{H}$, s, NH),7.30(2H, d, J=7.2Hz, ArCH), $7.32(2 \mathrm{H}, \mathrm{d}$ $\mathrm{J}=7.6 \mathrm{~Hz}, \mathrm{ArCH}), 8.20(1 \mathrm{H}, \mathrm{s}, \mathrm{NH}) \cdot{ }^{13} \mathrm{C} \mathrm{NMR}(100$ $\left.\mathrm{MHz}, \mathrm{CDCl}_{3}-\mathrm{d}_{6}\right) \delta(\mathrm{ppm}) 14.4\left(\mathrm{CH}_{3}\right), 21.4\left(\mathrm{CH}_{3}\right), 40.3$ $\left(\mathrm{CH}_{2}\right), 122.2(2 \times \mathrm{ArCH}), 129.9(2 \times \mathrm{ArCH}), 136.1$

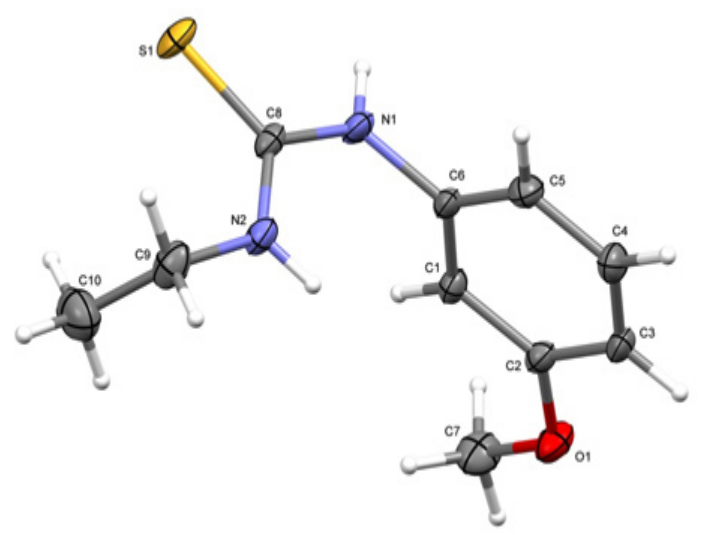

Fig. 1: ORTEP diagram of 1-Ethyl-3-(3methoxyphenyl)thiourea 1e
$(\operatorname{ArC}), 140.4(\operatorname{ArC}), 180.2(C=S) . m / z(E S I)\left(\mathrm{H}^{+}\right.$, $\mathrm{C}_{10} \mathrm{H}_{14} \mathrm{~N}_{2} \mathrm{~S}$ requires 195.09)

1c Mp: $97.4-98.8^{\circ} \mathrm{C} . \mathrm{IR}(\mathrm{KBr}), \mathrm{NH}: 3198.00$ $\mathrm{cm}^{-1}, \mathrm{C}-\mathrm{N}: 1317.00 \mathrm{~cm}^{-1}, \mathrm{C}=\mathrm{S}: 1249.00 \mathrm{~cm}^{-1} .{ }^{1} \mathrm{H} \mathrm{NMR}$ (400 MHz, $\mathrm{CDCl}_{3}-\mathrm{d}_{6}$ ) $\delta(\mathrm{ppm}) 1.16(3 \mathrm{H}, \mathrm{t}, \mathrm{J}=7.2 \mathrm{~Hz}$, $\left.\mathrm{CH}_{3}\right), 2.36\left(3 \mathrm{H}, \mathrm{s}, \mathrm{CH}_{3}\right), 3.64\left(2 \mathrm{H}, \mathrm{s}, \mathrm{CH}_{2}\right), 5.95(1 \mathrm{H}$, s, NH), $7.10(1 \mathrm{H}, \mathrm{d}, \mathrm{J}=7.6 \mathrm{~Hz}, \operatorname{ArCH}), 7.20(1 \mathrm{H}, \mathrm{d}$, $\mathrm{J}=7.6 \mathrm{~Hz}, \mathrm{ArCH}), 7.32-7.33(2 \mathrm{H}, \mathrm{m}, \mathrm{ArCH}), 8.06(1 \mathrm{H}$, $\mathrm{s}, \mathrm{NH}) \cdot{ }^{13} \mathrm{C}$ NMR $\left(100 \mathrm{MHz}, \mathrm{CDCl}_{3}-\mathrm{d}_{6}\right) \delta(\mathrm{ppm}) 14.3$ $\left(\mathrm{CH}_{3}\right), 21.1\left(\mathrm{CH}_{3}\right), 40.3\left(\mathrm{CH}_{2}\right), 128.0-130.8(4 \mathrm{x}$ $\mathrm{ArCH}), 133.4(\operatorname{ArC}), 137.5(\operatorname{ArC}), 180.4(C=\mathrm{S}) . \mathrm{m} / \mathrm{z}$ (ESI) $\left(\mathrm{H}^{+}, \mathrm{C}_{10} \mathrm{H}_{14} \mathrm{~N}_{2} \mathrm{~S}\right.$ requires 195.09)

1d Mp: $72.5-72.5^{\circ} \mathrm{C}$. IR (KBr), NH:3335 $\mathrm{cm}^{-1}$, C-C aromatic: $1528 \mathrm{~cm}^{-1}, \mathrm{C}=\mathrm{S}: 1263 \mathrm{~cm}^{-1}$. ${ }^{1} \mathrm{H}$ NMR (400 MHz, CDCl $\left.-\mathrm{d}_{6}\right) \delta$ (ppm) 1.20(3H, $\left.\mathrm{t}, \mathrm{J}=7.2 \mathrm{~Hz}, \mathrm{CH}_{3}\right), 3.67\left(2 \mathrm{H}\right.$, sex, J=5.6Hz, $\left.\mathrm{CH}_{2}\right)$, $3.85\left(3 \mathrm{H}, \mathrm{s}, \mathrm{OCH}_{3}\right), 6.11(1 \mathrm{H}, \mathrm{s}, \mathrm{NH}), 6.98(1 \mathrm{H}, \mathrm{t}$, $\mathrm{J}=7.6 \mathrm{~Hz}, \mathrm{ArCH}), 7.23(1 \mathrm{H}, \mathrm{td} \mathrm{J}=6.4 \mathrm{~Hz}$ and $1.6 \mathrm{~Hz}$, $\operatorname{ArCH}), 7.31(1 \mathrm{H}, \mathrm{s}, \mathrm{ArCH}), 7.52(1 \mathrm{H}, \mathrm{s}, \mathrm{NH}) .{ }^{13} \mathrm{C} \mathrm{NMR}$ $\left(100 \mathrm{MHz}, \mathrm{CDCl}_{3}-\mathrm{d}_{6}\right) \delta$ (ppm) $14.3\left(\mathrm{CH}_{3}\right), 40.3\left(\mathrm{CH}_{2}\right)$, $55.7\left(\mathrm{OCH}_{3}\right), 112.0$ - $124.9(4 \times \mathrm{ArC}), 127.5(\mathrm{ArC})$, $152.4(\operatorname{ArC}), 180.3(C=S) \cdot \mathrm{m} / \mathrm{z}(\mathrm{ESI})\left(\mathrm{Na}, \mathrm{C}_{10} \mathrm{H}_{14} \mathrm{~N}_{2} \mathrm{OS}\right.$ requires $233.27 \mathrm{~g} / \mathrm{mol}$ )

1e Mp: $112.5-117.5^{\circ} \mathrm{C}$. IR( $\left.\mathrm{KBr}\right) \mathrm{NH}: 3343$ $\mathrm{cm}^{-1}, \mathrm{C}-\mathrm{C}$ aromatic: $1550 \mathrm{~cm}^{-1}, \mathrm{C}=\mathrm{S}: 1284 \mathrm{~cm}^{-1}$. ${ }^{1} \mathrm{H}$ NMR (400 MHz, CDCl$\left.{ }_{3}-\mathrm{d}_{6}\right) \delta(\mathrm{ppm}) 1.19(3 \mathrm{H}$, t, J=7.2Hz, CH$\left.H_{3}\right), 3.67\left(2 \mathrm{H}\right.$, sex, J=5.4Hz, CH${ }_{2}$, $3.80\left(3 \mathrm{H}, \mathrm{s}, \mathrm{OCH}_{3}\right), 6.11(1 \mathrm{H}, \mathrm{s}, \mathrm{NH}), 6.78(1 \mathrm{H}, \mathrm{dd}$, $\mathrm{J}=6.0 \mathrm{~Hz}$ and $2.0 \mathrm{~Hz}, \mathrm{ArCH}), 6.74(1 \mathrm{H}, \mathrm{t}, \mathrm{J}=2.0 \mathrm{~Hz}$, $\operatorname{ArCH}), 6.82(1 \mathrm{H}$, dd, $\mathrm{J}=6.0 \mathrm{~Hz}$ and $2.4 \mathrm{~Hz}, \mathrm{ArCH})$, 7.32 $(1 \mathrm{H}, \mathrm{t}, \mathrm{J}=8.0 \mathrm{~Hz}, \operatorname{ArCH}), 7.95(1 \mathrm{H}, \mathrm{s}, \mathrm{NH}) .{ }^{13} \mathrm{C}$

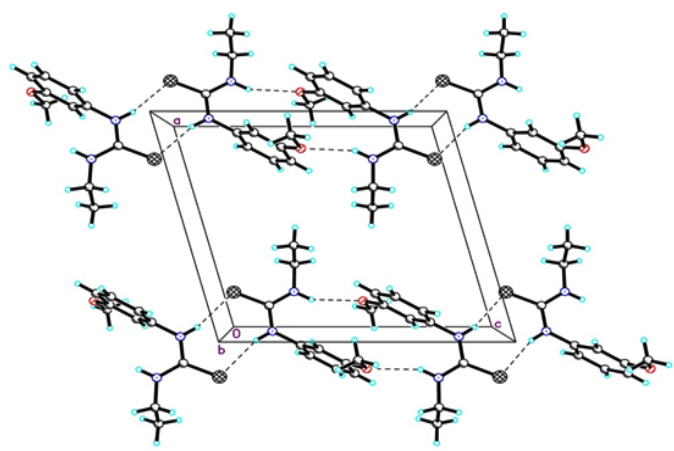

Fig. 2: Molecular packing of 1-ethyl-3-(3methoxyphenyl)thiourea $1 \mathrm{e}$ viewed down the $b$ axis. The dashed lines denote the $\mathrm{N}-\mathrm{H} \cdots \mathrm{S}$ and $\mathrm{N}-\mathrm{H} \cdots \mathrm{O}$ hydrogen bonds 
NMR (400 MHz, CDCl $\left.-\mathrm{d}_{6}\right) \delta(\mathrm{ppm}) 14.3\left(\mathrm{CH}_{3}\right)$, 40.4 $\left(\mathrm{CH}_{2}\right), 55.5\left(\mathrm{OCH}_{3}\right), 110.7-130.9(4 \times \mathrm{ArC}), 137.3$ $(\operatorname{ArC}), 160.9(\operatorname{ArC}), 180.1(C=S) . \mathrm{m} / \mathrm{z}(\mathrm{ESI})(\mathrm{Na}$, $\mathrm{C}_{10} \mathrm{H}_{14} \mathrm{~N}_{2} \mathrm{OS}$ requires $233.27 \mathrm{~g} / \mathrm{mol}$ )

1f Mp: $121.5-124.5^{\circ} \mathrm{C} . \mathrm{IR}(\mathrm{KBr}), \mathrm{NH}: 3297$ $\mathrm{cm}^{-1}$, C-H:2988 $\mathrm{cm}^{-1} \mathrm{C}-\mathrm{C}$ aromatic: $1520 \mathrm{~cm}^{-1}$, $\mathrm{C}=\mathrm{S}: 1289 \mathrm{~cm}^{-1} .{ }^{1} \mathrm{H}$ NMR $\left(400 \mathrm{MHz}, \mathrm{CDCl}_{3}-\mathrm{d}_{6}\right)$ $\delta(\mathrm{ppm}) 1.15\left(3 \mathrm{H}, \mathrm{t}, \mathrm{J}=7.2 \mathrm{~Hz}, \mathrm{CH}_{3}\right), 3.64(2 \mathrm{H}$, sex,

Table 1: Crystal data and structure refinement of 1-ethyl-3-(3-methoxyphenyl)thiourea 1e

\begin{tabular}{|c|c|}
\hline Crystal parameters & Data/values \\
\hline Empirical formula & $\mathrm{C}_{10} \mathrm{H}_{14} \mathrm{~N}_{2} \mathrm{OS}$ \\
\hline Formula weight & 210.29 \\
\hline Temperature & $302(2) \mathrm{K}$ \\
\hline Wavelength $\lambda$ & $0.71073 \AA$ \\
\hline Crystal system & Monoclinic \\
\hline Space group & $\mathrm{P} 21 / \mathrm{c}$ \\
\hline Unit cell dimensions & $\begin{array}{c}a=11.0797(7) \AA \\
\alpha=90^{\circ} \\
b=8.6081(6) \AA \\
\beta=104.543(2)^{\circ \circ} \\
c=11.9698(7) \AA \\
\gamma=90^{\circ}\end{array}$ \\
\hline Volume & $1105.04(12) \AA^{3}$ \\
\hline Z & 4 \\
\hline $\mathrm{D}, \mathrm{cal}\left(\mathrm{Mg} / \mathrm{m}^{3}\right)$ & 1.264 \\
\hline Absorption coefficient & $0.263 \mathrm{~mm}^{\prime \prime 1}$ \\
\hline$F(000)$ & 448 \\
\hline Crystal dimension $\left(\mathrm{mm}^{3}\right)$ & $0.44 \times 0.37 \times 0.29$ \\
\hline $\begin{array}{l}\text { Theta range for } \\
\text { data collection }\end{array}$ & 2.89 to $28.40^{\circ}$ \\
\hline Reflections collected & 40490 \\
\hline Ranges/indices $(\mathrm{h}, \mathrm{k}, \mathrm{l})$ & $-14,14 ;-11,11 ;-15,15$ \\
\hline Completeness to theta & $28.40^{\circ}, 99.6 \%$ \\
\hline Independent reflections & $2753[R($ int $)=0.0791]$ \\
\hline $\begin{array}{l}\text { Max. and min. } \\
\text { transmission }\end{array}$ & 0.9275 and 0.8929 \\
\hline $\begin{array}{l}\text { Data / restraints / } \\
\text { parameters }\end{array}$ & 2753 / 2 / 137 \\
\hline Goodness of fit on $\mathrm{F}^{2}$ & 1.100 \\
\hline R1, wR2 (I $\geq 2 \sigma(I))$ & $\begin{aligned} \mathrm{R} 1 & =0.0580, \mathrm{wR} 2 \\
& =0.1072\end{aligned}$ \\
\hline R1,wR2 indices (all data) & $\begin{array}{c}\mathrm{R} 1=0.1024, \mathrm{wR} 2 \\
=0.1220\end{array}$ \\
\hline $\begin{array}{l}\text { Largest diff. peak and } \\
\text { hole }\end{array}$ & 0.230 and -0.285 e. $\AA^{-3}$ \\
\hline
\end{tabular}

$\left.\mathrm{J}=5.6 \mathrm{~Hz}, \mathrm{CH}_{2}\right), 3.82\left(1 \mathrm{H}, \mathrm{s}, \mathrm{OCH}_{3}\right), 5.78(1 \mathrm{H}, \mathrm{s}, \mathrm{NH})$, $6.93(1 \mathrm{H}, \mathrm{d}, \mathrm{J}=8.8 \mathrm{~Hz}, \mathrm{ArCH}), 7.14(1 \mathrm{H}, \mathrm{d}, \mathrm{J}=8.8 \mathrm{~Hz}$, $\mathrm{ArCH}), 7.72(1 \mathrm{H}, \mathrm{s}, \mathrm{NH}) \cdot{ }^{13} \mathrm{C} \mathrm{NMR}\left(400 \mathrm{MHz}, \mathrm{CDCl}_{3}-\right.$ $\left.\mathrm{d}_{6}\right) \delta(\mathrm{ppm}) 14.4\left(\mathrm{CH}_{3}\right), 40.2\left(\mathrm{CH}_{2}\right), 55.5\left(\mathrm{OCH}_{3}\right)$, 115.2 - 127.7 $(4 \times \operatorname{ArC}), 128.6(\operatorname{ArC}), 158.8(\operatorname{ArC})$, $180.8(C=S) . \mathrm{m} / \mathrm{z}(\mathrm{ESI})\left(\mathrm{Na}, \mathrm{C}_{10} \mathrm{H}_{14} \mathrm{~N}_{2} \mathrm{OS}\right.$ requires $233.27 \mathrm{~g} / \mathrm{mol})$

\section{General procedure for naked-eye sensor}

For naked-eye sensor detection of metal ions ( $\mathrm{Fe}^{2+}, \mathrm{Pb}^{2+}, \mathrm{Hg}^{2+}, \mathrm{Ni}^{2+}, \mathrm{Zn}^{2+}, \mathrm{Ag}^{+}, \mathrm{Cu}^{2+}$, and $\mathrm{Sn}^{2+}$ ), compounds $\mathbf{1 a}, \mathbf{1} \mathbf{b}$ and $\mathbf{1 d}$ were dissolved in $25 \mathrm{ml}$ dimethyl sulfoxide (DMSO) to form $1 \times 10^{-3} \mathrm{M}$ solution. Metal ion sources were prepared in deionized water to form $1 \times 10^{-3} \mathrm{M}$ stock solution except $\mathrm{SnCl}_{2}$ in DMSO. The color changes were observed by naked eyes and the data were collected.

\section{RESULTS AND DISCUSSIONS}

All ethyl thiourea compounds $\mathbf{1 a} \mathbf{- 1 f}$ were synthesized in moderate to high yields from the reaction of ethylisothiocyanate $\mathbf{2}$ with isomers of toluidine $\mathbf{3} \mathbf{a}-\mathbf{3} \mathbf{c}$ and anisidine $\mathbf{3 d} \mathbf{-} \mathbf{3} \mathbf{f}$ in dichloromethane under reflux condition. Scheme 1 outlines the synthesis of ethyl thiourea compounds 1a-1f.

FT-IR spectra were taken with $\mathrm{KBr}$ pellets between 4000 and $400 \mathrm{~cm}^{-1}$. In the FT-IR spectra of all the synthesized compounds show sharp and strong absorption band in the region of $3011-3335$ $\mathrm{cm}^{-1}$ and it were attributed to the stretching vibration of $\mathrm{NH}$ group, respectively. In addition, synthesized compounds show strong intensity $\mathrm{C}=\mathrm{S}$ stretching vibration in the $1213-1284 \mathrm{~cm}^{-1}$ range. The proton

Table 2: Selected bond lengths and angles of 1-Ethyl-3-(3-methoxyphenyl)thiourea 1e

\begin{tabular}{cccc}
\hline Bond & Length A & Bond & Angles $^{\circ}$ \\
\hline S1-C8 & $1.6917(18)$ & C2-O1-C7 & $118.32(16)$ \\
O1-C2 & $1.366(2)$ & C8-N1-C6 & $124.92(16)$ \\
O1-C7 & $1.420(3)$ & C8-N2-C9 & $124.91(17)$ \\
N1-C8 & $1.339(3)$ & O1-C2-C3 & $115.78(16)$ \\
N1-C6 & $1.436(2)$ & O1-C2-C1 & $124.25(18)$ \\
N2-C8 & $1.326(3)$ & C5-C6-N1 & $119.26(18)$ \\
N2-C9 & $1.456(3)$ & C1-C6-N1 & $119.36(17)$ \\
\hline
\end{tabular}


NMR spectrum $\left({ }^{1} \mathrm{H}\right.$ and $\left.{ }^{13} \mathrm{C}\right)$ were in agreement with compounds $1 \mathrm{a}-\mathbf{1 f}$. The peaks in the region of $7.60-8.20 \mathrm{ppm}$ were attributed to $\mathrm{NH}$ proton near the aromatic ring. This singlet $\mathrm{NH}$ resonance is more de-shielded due to anisotropic effect. The distinctive broad singlets in the range of $5.65-6.20 \mathrm{ppm}$ were attributed to $\mathrm{NH}$ proton attached to the ethyl terminal ring. The present of electron donating ethyl moieties increased the electron density and shifted the protons of $\mathrm{NH}$ to the upfield position. The protons at aromatic ring were assigned at $6.80-7.36 \mathrm{ppm}$. The protons for methyl $(\mathbf{1 a}-\mathbf{1 c})$ and methoxy $(\mathbf{1 d}-\mathbf{1 f})$ at aromatic ring exhibited signal as singlet in the range of $2.28-2.36 \mathrm{ppm}$ and $3.80-3.85 \mathrm{ppm}$, respectively. The peaks in the region of 1.1 to $3.7 \mathrm{ppm}$ were due to the protons of methylene and methyl of ethyl ring. According to the ${ }^{13} \mathrm{C}$ NMR spectra, the signal of $\mathrm{C}=\mathrm{S}$ ring was found around $180.2 \mathrm{ppm}$ and indicated the formation of thiourea moiety. The aromatic carbons were observed in the range of $110.7-160.9 \mathrm{ppm}$ for all compounds. The methyl $(1 \mathrm{a}-1 \mathrm{c})$ and methoxy (1d-1f) carbons for aromatic ring were resonated at 21.0 and $55.5 \mathrm{ppm}$, respectively. All other carbons at the ethyl terminal ring were resonated in the region of<smiles>[R]NC(=S)N[R]</smiles>

Scheme 2: Resonance structure of thiourea
$14.3-40.3 \mathrm{ppm}$. The signal related to $[\mathrm{M}+\mathrm{H}]^{+}$and $[\mathrm{M}+\mathrm{Na}]^{+}$for compounds $\mathbf{1 b}$ and $\mathbf{1 d}$ in the MS spectrum were observed at 195.09 and 233.27, respectively.

X-ray diffraction study indicates that the compound 1e crystallizes in the monoclinic crystal system with space group of $\mathrm{P} 21 / \mathrm{n}$ and the unit cell dimension are $a=11.0797(7) \AA$, $b=8.6081(6) \AA, c=$ 11.9698(7) $\AA, \alpha=90^{\circ}, \beta=104.543(2)^{\circ}, \gamma=90^{\circ}, Z=4$ and $V=1105.04(12) \AA^{3}$. Crystallographic data have been deposited with the Cambridge Crystallographic Data Centre as supplementary publication number CCDC 1493627. Summary of the data collections and details of the structure refinement is given in Table 1.

Fig. 1 shows the molecular structure with numbering scheme of compound1e which is analogous to the previously reported 1-(2-Hydroxyethyl)-3-(3-methoxyphenyl)thiourea (Choi et al. 2010) except in 1e compound, there is no hydroxyl group bonded to the terminal carbon of ethyl group.

The molecule is not planar. However, the thiourea fragment $\mathrm{S} 1 / \mathrm{N} 1 / \mathrm{N} 2 / \mathrm{C} 8 / \mathrm{C} 9$ and the benzene ring $(\mathrm{C} 1-\mathrm{C} 6)$ are essentially planar with a maximum deviation of $0.003(2) \AA$ for $\mathrm{N} 2$ atom from the least square plane of the thiourea fragment. The

Table 3: Hydrogen geometric parameters (Å) of 1-Ethyl-3-(3-methoxyphenyl)thiourea 1e

\begin{tabular}{|c|c|c|c|c|}
\hline$D^{-} H^{\prime} \cdots A$ & $\mathrm{D}^{-} \mathrm{H}$ & $\mathrm{H \cdots A}$ & $D \cdots A$ & $D^{-} H^{\prime} \cdots A$ \\
\hline $\mathrm{N} 1^{-} \mathrm{H} 1 \mathrm{~A} \cdots \mathrm{S} 1^{i}$ & $0.866(14)$ & $2.528(16)$ & $3.3678(18)$ & $163.6(16)$ \\
\hline $\mathrm{N} 2^{-} \mathrm{H} 2 \mathrm{~A}^{\cdots \cdots} \mathrm{O} 1^{1 i}$ & $0.865(19)$ & $2.331(17)$ & $3.126(2)$ & $152.9(19)$ \\
\hline
\end{tabular}

Symmetry codes: $i=-x, 1-y,-z, \quad i i=-x, 1-y, 1-z$

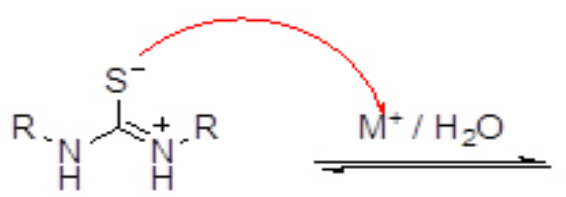<smiles>[R]NC([N+])=[N+][O-]</smiles><smiles>CCCC</smiles><smiles>[R]N=C(N[R])S[N+]</smiles>

$$
\mathrm{M}^{+}=\mathrm{Hg}^{2+}, \mathrm{Ag}^{+}
$$

Scheme 3: Reaction scheme of thiourea binding with metal ions 


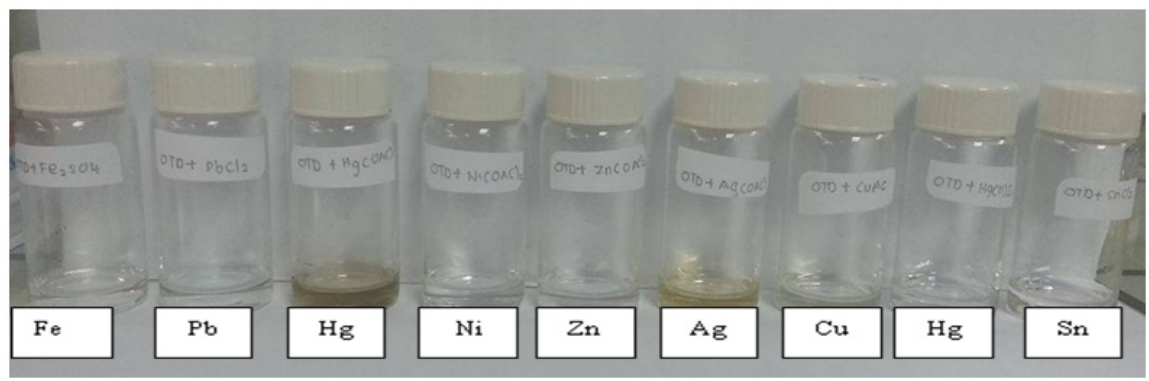

1a

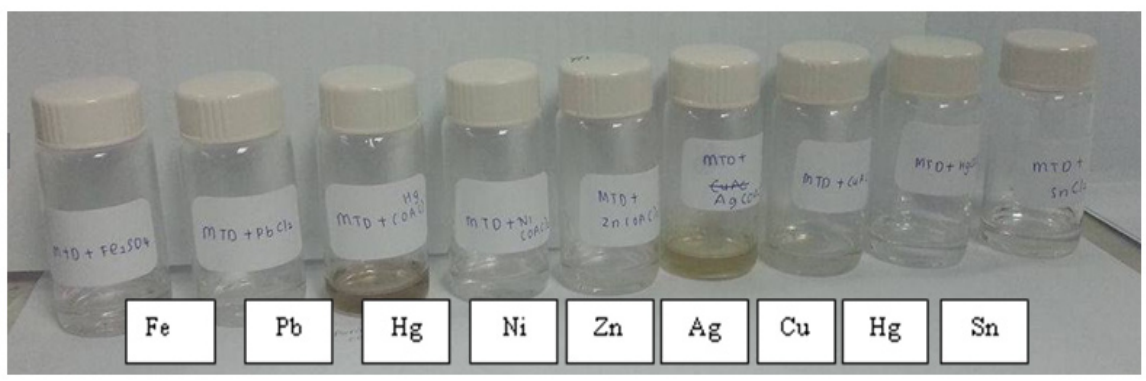

$1 b$

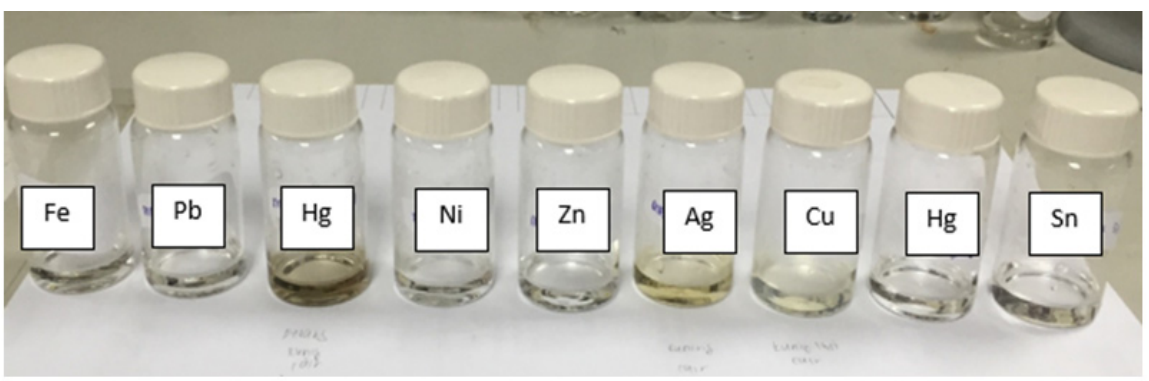

1d

Fig. 3: The interaction of compound $1 \mathrm{a}, 1 \mathrm{~b}$ and $1 \mathrm{~d}$ with metal cations

two planes forming a dihedral angle of $88.54(9)^{\circ}$, which is considerably bigger than that found in 1-(2-Hydroxyethyl)-3-(3-methoxyphenyl)thiourea of $62.57(4)^{\circ}$. Other bond lengths and angles are comparable to those in the analog and lie in normal ranges (Table 2).

The intramolecular hydrogen bonds does not exists in the molecule while in the crystal packing the molecules are linked by $\mathrm{N} 1-\mathrm{H} 1 \mathrm{~A}$...S 1 and N2-H2A...O intermolecular hydrogen bonds (Table 3), to form infinite one-dimensional chains along the $c$ axis (Fig. 2).

The ability and sensor features of compounds 1a, $\mathbf{1 b}$ and $\mathbf{1 d}$ were investigated using the naked-eye in DMSO solvent mixture in the presence of metals such as $\mathrm{Fe}, \mathrm{Pb}, \mathrm{Hg}, \mathrm{Ni}, \mathrm{Ag}, \mathrm{Cu}$ and $\mathrm{Sn}$. It was determined that ethyl thiourea as 1a - 1f did not exhibit naked-eye sensor properties for $\mathrm{Fe}, \mathrm{Pb}, \mathrm{Ni}, \mathrm{Cu}$ and $\mathrm{Sn}$ metals. However, the compounds exhibited selective sensor behavior for $\mathrm{Hg}^{+}$and $\mathrm{Ag}^{+}$metal ions (Fig. 3).

Thiourea derivatives contain a relatively basic $\mathrm{C}=\mathrm{S}$ group that interacts with the metal ions. The $\mathrm{C}=\mathrm{S}$ bond which was weak and had the resonance structure (Scheme 2) was the dominant resonance contributor. ${ }^{8}$ The resonance structure will be the nucleophile to attack the metal ions to form a stable complex (Scheme 3). 


\section{CONCLUSIONS}

In the present work, ethyl thiourea 1a - 1f were prepared from the simple reaction method and are characterised using various spectral techniques. From the X-ray crystallography study of $1 \mathbf{e}$, molecule crystallized in a monoclinic crystal system with space group of $P 21 / n$ and the unit cell dimensions are $a=11.0797(7) \AA, b=8.6081(6) \AA$, $c=11.9698(7) \AA, \alpha=90^{\circ}, \beta=104.543(2)^{\circ}, \gamma=90^{\circ}$, $Z=4$ and $V=1105.04(12) \AA^{3}$. Preliminary study showed that ethyl thiourea $\mathbf{1 a}, \mathbf{1} \mathbf{b}$ and $\mathbf{1 d}$ have the ability as naked eye sensors for mercury $(\mathrm{Hg})$ and argentum $(\mathrm{Ag})$ metal ions.

\section{ACKNOWLEDGEMENT}

The authors thank the Ministry of Higher Education of Malaysia and University Kebangsaan Malaysia for the research grant FRGS1/2015/ST01/UKM/02/2 and PRGS/2/2015/SG01/UKM/02/1 for the X-ray facility.

\section{REFERENCES}

1. Abdul Fattah, M. A.; Lusta, I. Z.; Zubi, A. E.International Scholarly and Scientific Research \& Innovation 2014, 8(2), 116-118.

2. Alkan, C.; Tek, Y.; Kahraman, D. Turkish Journal of Chemistry 2011, 35(5), 769-777.

3. Mertschenk B.; Beck F.; Bauer W. Weinheim: Wiley-VCh Verlag GmbH \& Co. KGaA.1995.

4. Zhao J.; Cui G. International Journal of Electrochemical Science 2011, 6, 4048 4058.

5. Asieh Y.; Zahra G. Eur. Chem. Bull. 2013, 2(8), 573-575.

6. Rurack, K.; Resch-Genger, U. Chemical Society Reviews 2002, 31(2): 116-127.

7. Jae-Young L.; Boddu Ananda R.; Ji-Yong H.; and Young-A. S.Sensors and Actuators B 2015, 220, 1070-1085.

8. Zhang, H.; Gu, C. D.; Huang, M. L.; Wang, X. L.; Tu, J. P. Electrochemistry Communications 2013, 35, 108-111

9. Berger, T.; Spadaro, J.; Chapin, S.; Becker, R. Antimicrobial Agents and Chemotherapy
1976, 9(2), 357

10. Panyala, N. R.; Peña-Méndez, E. M.; Havel, J. J Appl Biomed, 2008, 6(3), 117-129.

11. Li, X.; Gao, X.; Shi, W.; Ma, H. Chemical Reviews 2013, 114(1), 590-659.

12. Kumar V.; Kaushik M.P.; Srivastava A.K.; Pratap A.; Thiruvenkatam V.; Guru Row T. N. Analytica Chimica Acta 2010, 663, 77-84.

13. Valeur, B.; Leray, I. Coordination chemistry reviews 2000, 205(1), 3-40.

14. Abosadiya, H. M.; Siti Aishah Hasbullah; Bohari M Yamin. Spectrochimica Acta Part A: Molecular and Biomolecular Spectroscopy 2015, 144, 115-124.

15. Saeed S.; Rizwan Hussain. Eur. Chem. Bull. 2013, 2(7), 465-467.

16. Arslan H.; Duran N.; Borekci G.; Koray O.; Akbay C. Molecules 2009, 14, 519-522.

17. Sheldrick, G. M. SHELXTL. Version 6.14. Program for Crystal Structure Determination. University of Gottingen: Gottingen, Germany 1997. 